\title{
Comparing 48-Person Lineups with a 96-Person Lineup
}

\author{
Avraham Levi* \\ Department of Israeli Police, Jerusalem, Israel \\ *Corresponding author: Avraham Levi, Department of Israeli Police, Jerusalem, Israel
}

\begin{abstract}
There is insufficient data on the effect of lineup size on identifications in large lineups. This study therefore compared 48-person lineups, a size used often in large lineup experiments, with a lineup double the size, 96 . At least one hour after viewing a two-minute video featuring the target, other people and other objects, 52 participants viewed 48-person lineups (four screens of 12) or a 96-person lineup (eight screens of 12). No difference was found in the rate of identifications between the two lineup sizes. The conclusion is that the larger lineup is superior due to the smaller chance of mistakenly choosing an innocent suspect.
\end{abstract}

\section{Introduction}

A fair lineup is one in which each of the foils and the innocent or guilty suspect have an equal chance of being chosen by people who have never seen the suspect ["mock witnesses", Doob \& Kirshenbaum [1], who have been given a description of the target]. The lineup is the safest eyewitness identification procedure, because the foils provide some protection to an innocent suspect. However, it is far from perfect. There is ample evidence that witnesses often choose someone who is not the culprit Conners et al. [2]; Scheck, Neufeld, \& Dwyer [3], Valentine, Pickering \& Darling [4]; Wells et al. [5]. When they choose, and that person is not the suspect but a known innocent, the police know that they have erred. However, in a fair simultaneous lineup by chance these witnesses who choose "identify" a suspect who is innocent $1 / \mathrm{N}$ times, where $\mathrm{N}$ is the lineup size. With the common American lineup size of six, this will happen $1 / 6=0.167$, or almost $17 \%$ of the time. There is a second error that witnesses often make which goes undetected by the police: witnesses fail to identify guilty suspects Levi [6]. While a number of innovative lineup procedures have been developed to reduce mistaken identifications Levi [7], Levi [8], Pryke et al. [9], there have been few procedures available to increase correct ones that do not simultaneously increase mistaken ones. The danger of mistaken identifications has been considered so great that in the wake of research showing that we can reduce them if we warn witnesses that the culprit may not be in the lineup Malpass \& Devine [10] the warning has been included in one of four recommendations of a White Paper of the American Psychological Association Wells et al. [5] to improve lineup identification evidence.
Yet experimental witnesses choose someone $57 \%$ of the time when the "culprit" is absent when shown a simultaneous lineup Steblay, Dysart, and Wells [11], even with the warning. In a fair lineup, the innocent suspect will be chosen in the traditional sixperson American lineup 57/6 $=9.5 \%$ of the time. This seems quite a large danger for an innocent suspect. Lindsay and Wells introduced sequential lineups. Their data, and a meta-analysis Steblay et al. [11], indicate that its chief advantage is in reduced mistaken identifications. Only 36\% mistaken choices in culprit-absent lineups are made. Thus, in the traditional six-person American lineup the innocent suspect will be chosen $36 / 6=6 \%$ of the time. This remains too large a large danger for an innocent suspect Dupuis \& Lindsay [12]. Levi and Lindsay [13] proposed exploring large lineups. They theorized that enlarging lineups could reduce false recognitions, if the rate by which witnesses chose someone in target-absent lineups increased less than the increased lineup size. Thus, if a 40-person lineup had the same rate of mistaken choices as the six-person lineup, the number of false identifications would be $57 / 40=1.04 \%$. This would clearly be a tremendous improvement. Levi [8] has been experimenting with very large lineups, the largest consisting of 120 members. The two consistent findings have been that both the number of correct identifications and the amount of choosing when the target is absent (mistaken choices) remains constant and comparable to small lineups even as the lineup grows from 24 to 120 members. The result has been a dramatic reduction in mistaken identifications at no cost to correct ones. For example, with a typical rate of $50 \%$ mistaken choices in the traditional six- 
person target absent simultaneous lineup, if the lineup is fair the expected rate of mistaken identifications is $50 / 6=8.3 \%$. With a lineup of 48 , the same percentage of mistaken choices leads to $50 / 48=1 \%$ mistaken identifications.

Levi has conducted a number of experiments using a twominute video as the eyewitness event, and a 48-person lineup Levi [14-20], Levi \& Menashe [21]. The rate of identifications of the target in target-present lineups was usually about 33\%. There is some doubt as to whether this rate will generalize to larger lineups. In Levi's original experiments Levi [8], the eyewitness event was very difficult. A student accompanied Levi when he recruited his participants. The student found a mutually acceptable time for the experiment and asked for the first name and phone number of the participant. He was clearly viewed by the participants are merely performing a clerical function for Levi, and thus minimal attention was given to him. When Levi arrived back and informed the participant that he was conducting a lineup and the person that they were to identify was the student, they found the task very difficult, and rates of identification very low. The fact that no difference was found in the rate of identification as the lineup grew in size may have been caused by a floor effect. If substantially increasing lineup size does not decrease the rate of identification, this has both important theoretical and practical implications. Substantial increases in lineup size reduces the rate of mistaken identifications, and therefore this would be an important improvement in actual police lineups. This experiment therefore compared the rate of identifications of the target in 48-person lineups with that rate in a 96-person lineup. Different 48-person lineups were made from different screens of the 96-person lineup, to ensure that identification rates have not been influenced by the particular photos in the additional four screens of the 96-person lineup.

\section{Method}

Participants: The 100 participants were graduate students engaged in research at Bar Ilan University, Tel Aviv University and the Hebrew University who agreed to participate in "a short and interesting" experiment, which would involve viewing immediately a two-minute video, and later participating in a five-minute experiment in their lab.

Design: Half of the participants viewed a 48-person lineup, the other 50 the 96-person one. The screen with the target was always shown, and shown for the first time in the first, second, third or fourth screen in 48-person lineups, or in the first, second, third, fourth, fifth, sixth, seventh or eighth position in the 96-person lineup (as could well be the case in real lineups. Three of the remaining seven screens was randomly shown for each of the 48-person lineups, with the limitation that no set of three screens was shown more than twice. The order of a 48-person lineup or 96-person one was also randomly determined, with the limitation that neither would be shown more than 52 times.
Recruitment and Eyewitness Event: The author visited labs at the university. He introduced himself and asked the occupant whether they would participate in an interesting experiment in their lab at a later time that would last only about five minutes. If a person agreed, he immediately showed them the video used in previous experiments lasting 2 minutes in which the target and other people were seen, well as numerous objects. He arranged a mutual acceptable time for the experiment, at least an hour later. The video and the lineup were shown on a tablet.

The lineups: Photos for the lineups were chosen from Levi [8]. All lineup members were young adult males who had dark and short hair, dark eyes, no beard or moustache, and were of medium build. The target also fit this description. The twelve faces of each screen were organized in two lines of six. The target was placed in the lower line one before the end from the right.

\section{Procedure:}

Participants Were Told: I am now going to conduct a lineup. The person you are to identify is the man who walked between the rooms. He may not be in the lineup. I will show you a 4 screens (for 48-person lineups, or 8 for the 96-person lineup), each containing twelve photos. All the photos are of different people. You may view the screens as many times are you wish before coming to a decision, whether the person is in the lineup, and if so who he is". Each participant was then shown the lineup.

\section{Results and Discussion}

The difference in number of identifications was tested using the test for the difference between two proportions Walpole [22]: $\mathrm{z}=0.074$, not even approaching significance. Since there is no difference in identifications between the lineups, the 96-person lineup is superior (Table 1). The chance of mistakenly identifying an innocent suspect in the 96-person lineup is half that of the 48-person lineup, assuming that there is no greater likelihood of mistakenly choosing someone in the larger lineup. Both the results in Levi [8] and the failure to find any difference in the number of foil choices between the two lineups supports this assumption.

Table 1: Presents the number of identifications of the target, identifications of foils or no identification, for each lineup size.

\begin{tabular}{|c|c|c|c|c|}
\hline TOTAL & NONE & FOIL & ID & \\
\hline 52 & $16(30 \%)$ & $25(48 \%)$ & $11(21 \%)$ & 48-person lineups \\
\hline 48 & $14(29 \%)$ & $27(56 \%)$ & $7(15 \%)$ & 96-person lineup \\
\hline
\end{tabular}

\section{References}

1. Doob AN, Kirshenbaum HM (1973) Bias in police lineups-partial remembering. Journal of Police Science and Administration 1: 287-293.

2. Conners E, Lundregan T, Miller N, McEwen T (1996) Convicted by juries, exonerated by science: Case studies in the use of DNA evidence to establish innocence after trial. Washington: U. S. Department of Justice, USA

3. Scheck B, Neufeld P, Dwyer J (2001) Actual innocence: When justice goes wrong and how to make it right. Signet, New York, USA. 
4. Valentine T, Pickering A, Darling S (2003) Characteristics of eyewitness identification that predict the outcome of real lineups. Applied Cognitive Psychology 17(8): 969-993.

5. Wells GL, Small M, Penrod S, Malpass RS, Fulero SM, et al. (1998) Eyewitness identification procedures: Recommendations for lineups and photospreads. Law and Human Behavior 22(6): 603-647.

6. Levi AM (1998) Are defendants guilty if they were chosen in a lineup? Law and Human Behavior 22(4): 389-407.

7. Levi AM (2006) An Analysis of Multiple Choices in MSL Lineups, and a Comparison with Simultaneous and Sequential ones. Psychology, Crime \& Law 12(3): 273-285.

8. Levi AM (2012) Much Better than the Sequential lineup: A 120-person lineup. Psychology, Crime \& Law 18(7): 631-640.

9. Pryke S, Lindsay RCL, Dysart JE, Dupuis P (2004) Multiple independent identification decisions: A method of calibrating eyewitness identifications. Journal of Applied Psychology 89(1): 73-84.

10. Malpass RS, Devine PG (1981) Eyewitness identification: Lineup instructions and the absence of the offender. Journal of Applied Psychology 66(4): 482-489.

11. Steblay NK, Dysart JE, Wells GL (2011) Seventy-two tests of the sequential lineup superiority effect: A Meta-Analysis and Policy Discussion. Psychology, Public Policy and Law 17(1): 99-139.

12. Dupuis PR, Lindsay RCL (2007) Radical alternatives to traditional lineups. In R Lindsay, R Ross, D Read, M Toglia (Eds.). Handbook of

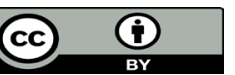

This work is licensed under Creative

Commons Attribution 4.0 License

To Submit Your Article Click Here:

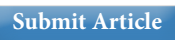

eyewitness psychology: Memory for people 2: 179-200.

13. Levi AM, Lindsay RCL (2001) Lineup and photo spread procedures: Issues concerning policy recommendations. Psychology, Public Policy and Law 7(4): 776-790.

14. Levi AM (2015) When the relative judgment theory proved to be false. Psychology and Law 5: 141-149.

15. Levi AM (2017) Comparing the English Video Lineup with the 48-Person Lineup. Universal Journal of Psychology 5(6): 239-243.

16. Levi AM (2018) Can We increase identifications in 48-person lineups by asking for ratings of all lineup members? Psychology and Behavioral Science 8: 1-5.

17. Levi AM (2018) The 48-person lineup. Scholarship Press.

18. Levi AM (2018)Comparing the 48-person lineup with the sequential lineup. Journal of Forensic and Crime Investigation 2(1).

19. Levi AM (2018) Partial memory: Another reason for using large lineups? Legal and criminological psychology.

20. Levi AM (under review) Testing partial memory using the British lineup clinical and experimental psychology.

21. Levi AM, Menasheh D (2017) Evidence for the superiority of the 48-person lineup. Journal of Psychology and Cognition 2(4): 231-236.

22. Walpole RE (1968) Introduction to statistics. New York: Macmillan Company.

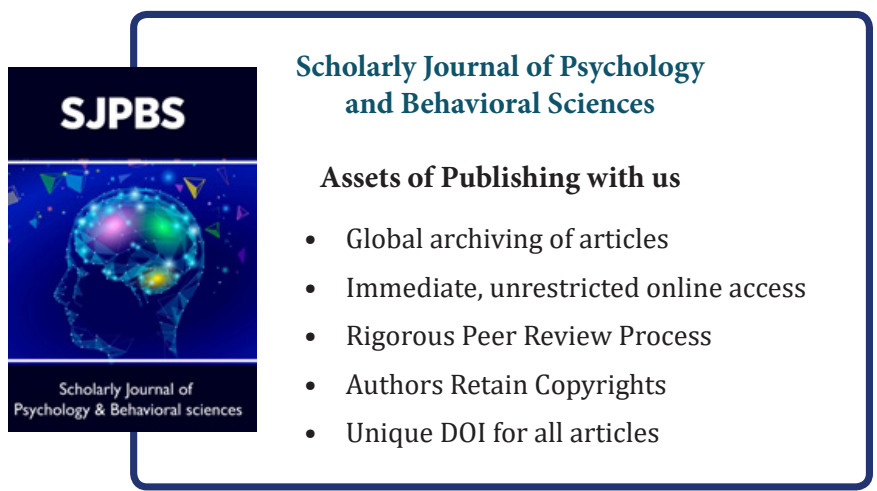

